\title{
A Novel 1,4-Addition Type Reaction of $\beta$-Keto Esters with Vinyl Ketones Catalyzed by Iron(II)tetrafluoroborate in an Ionic Liquid Solvent System
}

\author{
Hiroyuki Uehara, Shun Nomura, Shuichi Hayase, Motoi Kawatsura, \\ and Toshiyuki ITOH*
}

Department of Materials Science, Faculty of Engineering, Tottori University (Tottori 680-8552, Japan)

Received February 2, 2006 ; Accepted April 21, 2006

\begin{abstract}
The 1,4-addition reaction of several $\beta$-ketoesters with vinyl ketones has been accomplished using iron(II)tetrafluoroborate $\left(\mathrm{Fe}\left(\mathrm{BF}_{4}\right)_{2} \cdot 6 \mathrm{H}_{2} \mathrm{O}\right)$ as catalyst under air atmospheric conditions at room temperature in an acetonitrile or an ionic liquid solvent system. Recycled use of the catalyst was possible while maintaining excellent yield in the ionic liquid solvent system.
\end{abstract}

Key Words : 1,4-Addition, Vinyl ketone, $\beta$-Ketoester, Iron(II)tetrafluoroborate catalyst, Ionic Liquids

\section{Introduction}

Iron is recognized as an economical and pollution free metal source. ${ }^{1)}$ Recently we demonstrated several types of iron salt-catalyzed reactions: the intramolecular cyclization of cyclopropanonedithioacetals, $\left.{ }^{2}\right)[2+2]-$ cycloaddition of (trans)-anethol, ${ }^{3}$ ) and [2+3]-type cycloaddition of styrene derivatives with 1,4-benzoquinone. $^{4}$ In particular, it was established that the reaction was greatly accelerated in an ionic liquid solvent system. ${ }^{4,5}$ )

The 1,4-addition of appropriate donor molecules such as active methylene compounds with $\alpha, \beta$-unsaturated carbonyl compounds is widely recognized as one of the most important $\mathrm{C}-\mathrm{C}$ bond forming reactions in organic synthesis. ${ }^{6)}$ Although these reactions have been catalyzed by strong bases, transition-metal catalysis of the 1,4-additions have recently been developed as a valuable alternative to the classic base catalyzed reaction. ${ }^{6-9)}$ Various types of transition metal catalysts have been developed. As examples, Christoffers ${ }^{7)}$ reported iron(III)-catalyzed Michael reactions of 1,3-dicarbony compounds with enones. Further, Shimizu and co-workers ${ }^{8)}$ recently demonstrated that $\mathrm{Fe}^{3+}$-exchanged fluorotetrasilicic mica acted as an effective catalyst for the 1,4-addition of $\beta$-ketoesters $\mathbf{1}$ with vinyl ketones 2 . Since this was proposed to be a Lewis acid promoted reaction, ${ }^{7,8)}$ we tested the reaction of ethyl 2-oxocyclopentanecarboxylate $(\mathbf{1 a})\left(\mathrm{R}^{1}, \mathrm{R}^{2}=-\left(\mathrm{CH}_{2}\right)_{3^{-}}\right)$with 3-oxobut-1-ene $(2 \mathbf{a})\left(\mathrm{R}^{3}=\mathrm{Me}\right)$ as a model reaction using $3 \mathrm{~mol} \%$ of $\mathrm{Fe}\left(\mathrm{ClO}_{4}\right)_{3} \cdot \mathrm{Al}_{2} \mathrm{O}_{3}$ as catalyst in acetonitrile $\left(\mathrm{CH}_{3} \mathrm{CN}\right)$, but the desired product $\mathbf{3} \mathbf{a}^{7}$ was obtained in poor yield (25\%) (Eq. 1, Table 1, Entry 1). Fortunately, we found that the chemical efficiency was drastically improved and desired 3a was obtained in $57 \%$ yield when the reaction was carried out in the presence of $3 \mathrm{~mol} \%$ of iron(II)tetrafluoroborate $\left(\mathrm{Fe}\left(\mathrm{BF}_{4}\right)_{2} \cdot 6 \mathrm{H}_{2} \mathrm{O}\right)$ as catalyst in $\mathrm{CH}_{3} \mathrm{CN}$ at room temperature (rt) for 6 hours under argon atmosphere conditions (Entry 2). Since there has been no report concerning the Lewis acidic property of $\mathrm{Fe}\left(\mathrm{BF}_{4}\right)_{2}$, the results prompted us to investigate the details of the
$\mathrm{Fe}\left(\mathrm{BF}_{4}\right)_{2}$-catalyzed 1,4-addition of $\beta$-ketoester with vinyl ketones. In this paper, we report that the 1,4-addition reaction of $\beta$-ketoester with vinyl ketones was accomplished by $\mathrm{Fe}\left(\mathrm{BF}_{4}\right)_{2} \cdot 6 \mathrm{H}_{2} \mathrm{O}$ as catalyst, and the catalyst was used repeatedly more than 10 times in an ionic liquid solvent system.

\section{Experimental}

A typical reaction was carried out as follows: to a solution of 1a (156 mg, $1.0 \mathrm{mmol})$ and $\mathbf{2 a}(105 \mathrm{mg}, 1.5 \mathrm{mmol})$ in $[$ bmim $]\left[\mathrm{NTf}_{2}\right](1.0 \mathrm{ml})$ was added $\mathrm{Fe}\left(\mathrm{BF}_{4}\right)_{2} \cdot 6 \mathrm{H}_{2} \mathrm{O}(10$ $\mathrm{mg}, 0.03$ eq.) in one portion, and the mixture was stirred at $\mathrm{rt}$ for $2 \mathrm{~h}$, then extracted with ether $(0.5 \mathrm{ml} \times 10)$. The organic layer was filtered through a florisil short column, evaporated to dryness and purified by silica gel flash column chromatography to give $\mathbf{3 a}{ }^{7)}$ (215 mg, $0.95 \mathrm{mmol}$ ) in $95 \%$ yield. The ionic layer was stored as acetone solution and used repeatedly after our recycling procedure ${ }^{10)}$ : ${ }^{1} \mathrm{H}$ NMR (500 MHz, $\left.\delta, \mathrm{CDCl}_{3}, \mathrm{~J}=\mathrm{Hz}\right) 1.19(3 \mathrm{H}, \mathrm{t}, \mathrm{J}=7.4$ ), 1.80-2.00 (6H, m), 2.08 (3H, s), 2.20-2.70 (4H, m), 4.10 (2H, q, $\mathrm{J}=7.4) ;{ }^{13} \mathrm{C}$ NMR (50 $\left.\mathrm{MHz}, \mathrm{ppm}, \mathrm{CDCl}_{3}\right)$ 13.79, 19.30, 26.69, 29.62, 33.97, 37.67, 38.57, 58.68, 61.10, 171.07, 207.47, 214.59; IR (neat, $\mathrm{cm}^{-1}$ ) 2779, 1747, 1717, 1367, 1165, 1029.9, 860.2 .

$\left.3 b^{7}\right) \quad\left(R^{1}, R=M e, R^{2}=H\right)$ : Rf 0.33 (hexane: ethyl acetate $=2 / 1){ }^{1} \mathrm{H}$ NMR $\left(500 \mathrm{MHz}, \delta, \mathrm{CDCl}_{3}, \mathrm{~J}=\mathrm{Hz}\right) 1.21$ (3H, t, J = 7.3), 2.03 (2H, quint, $\mathrm{J}=6.9), 2.07(3 \mathrm{H}, \mathrm{s}), 2.18$ (3H, s), 2.43 (2H, t, J = 6.9), $3.43(1 \mathrm{H}, \mathrm{t}, \mathrm{J}=6.9), 4.13(2 \mathrm{H}, \mathrm{q}$, $\mathrm{J}=7.4) ;{ }^{13} \mathrm{C} \mathrm{NMR}\left(125 \mathrm{MHz}, \delta, \mathrm{CDCl}_{3}\right) 13.83,21.41,28.76$, 29.67, 40.20, 57.97, 61.20, 169.25, 202.59, 207.23; IR (neat, $\mathrm{cm}^{-1}$ ) 2984, 1736, 1719, 1364, 1246, 1153, 1097, 1024, 858.

3c $\left(\mathrm{R}^{1}, \mathrm{R}^{2}=-\left(\mathrm{CH}_{2}\right)_{3^{-}}, \mathrm{R}=\mathrm{n}-\mathrm{C}_{5} \mathrm{H}_{11}\right)$ : Rf 0.43 (hexane: ethyl acetate $=4 / 1){ }^{1} \mathrm{H}$ NMR $\left(500 \mathrm{MHz}, \delta, \mathrm{CDCl}_{3}, \mathrm{~J}=\mathrm{Hz}\right) 0.81$ $(3 \mathrm{H}, \mathrm{t}, \mathrm{J}=7.3), 1.16-1.26(7 \mathrm{H}, \mathrm{m}), 1.49(2 \mathrm{H}$, quint, $\mathrm{J}=7.3)$, 1.78-2.07 (5H, m), 2.20-2.41 (6H, m), 2.55-2.62 (1H, m), 4.10(2H, q, J =6.4); ${ }^{13} \mathrm{C}$ NMR (125 $\left.\mathrm{MHz}, \delta, \mathrm{CDCl}_{3}\right)$ 13.87, $14.05,19.54,22.38,23.47,26.98,31.34,34.29,37.87,37.45$, 42.78, 59.03, 61.37, 171.38, 210.30, 214.88; IR (neat, $\mathrm{cm}^{-1}$ ) 2934, 1751, 1719, 1560, 1458, 1364, 1232, 1159, 1030; Anal. Calcd for $\mathrm{C}_{16} \mathrm{H}_{26} \mathrm{O}_{4}$ : C, 68.06; H, 9.28; Found: C, 68.03; H, 
9.28 .

3d $\left(\mathrm{R}^{1}, \mathrm{R}^{2}=-\left(\mathrm{CH}_{2}\right)_{3}-, \mathrm{R}=\mathrm{PhCH}_{2} \mathrm{CH}_{2}\right)$ : $\mathrm{Rf} 0.37$ (hexane: ethyl acetate $=4 / 1){ }^{1} \mathrm{H}$ NMR $\left(500 \mathrm{MHz}, \delta, \mathrm{CDCl}_{3}, \mathrm{~J}=\mathrm{Hz}\right)$ 1.15 (3H, t, J = 6.9), 1.73-2.05 (5H, m), 2.17-2.38 (4H, m), 2.54-2.60 (1H, m), $2.64(2 \mathrm{H}, \mathrm{t}, \mathrm{J}=8.2), 2.80(2 \mathrm{H}, \mathrm{t}, \mathrm{J}=7.3)$, $4.07(2 \mathrm{H}, \mathrm{q}, \mathrm{J}=7.3)$ 7.08-7.20 (5H, m); ${ }^{13} \mathrm{C} \mathrm{NMR}(125 \mathrm{MHz}$, $\left.\delta, \mathrm{CDCl}_{3}\right)$ 13.93, 13.96, 19.44, 26.82, 29.62, 34.13, 37.82, 38.05, 44.08, 58.88, 61.27, 125.93, 128.16, 128.33, 140.86, 171.22, 208.82, 214.66; IR (neat, $\mathrm{cm}^{-1}$ ) 2936, 1719, 1452, 1369, 1232, 1159, 1030, 860, 705, 700; Anal. Calcd for $\mathrm{C}_{16} \mathrm{H}_{26} \mathrm{O}_{4}$ : C, 72.13; H, 7.65; Found: C, 71.19; H, 7.60.

Recycling use of the catalyst: To a solution of 1a (156 $\mathrm{mg}, \quad 1.0 \mathrm{mmol})$ and $2 \mathbf{a}(105 \mathrm{mg}, 1.5 \mathrm{mmol})$ in [demmea][ $\left.\mathrm{NTf}_{2}\right](1.0 \mathrm{ml})$ was added $\mathrm{Fe}\left(\mathrm{BF}_{4}\right)_{2} \cdot 6 \mathrm{H}_{2} \mathrm{O}(10$ $\mathrm{mg}, 0.03$ eq.) in one potion, and the mixture was stirred at $\mathrm{rt}$. The reaction course was monitored by silica gel thin layer chromatography (TLC) analysis and the reaction was quenched by addition of ether immediately after 1a had been consumed. Addition ether to the reaction mixture formed the biphasic layer and the product 3a was isolated from the ether layer. The same process was repeated.

\section{Results and Discussion}

We anticipated that the real catalyst may be iron(III) species derived from $\mathrm{Fe}\left(\mathrm{BF}_{4}\right)_{2} \cdot 6 \mathrm{H}_{2} \mathrm{O}$ by the aerobic oxidation during performance of the reaction process. In fact, chemical yield of $\mathbf{3 a}$ was increased when the reaction was carried out under air atmospheric conditions; $3 \mathbf{a}$ was obtained in $73 \%$ (Entry 3 ) and the yield reached $80 \%$ yield when a small volume of air was bubbled into the solvent prior to the reaction (Entry 4). Using the same reaction conditions, $\mathbf{3 a}$ was obtained in the same yield even if $1 \mathrm{~mol} \%$ of catalyst (Entry 5) was used. Further, it was found that 3a was obtained in 67\% yield even when the reaction was carried out in the presence of only $0.1 \mathrm{~mol} \%$ of $\mathrm{Fe}\left(\mathrm{BF}_{4}\right)_{2} \cdot 6 \mathrm{H}_{2} \mathrm{O}$ (Entry 6), while the reaction speed depended on the amount of the catalyst. Although it was confirmed that the reaction proceeded in the presence of a trace amount of the Fe salt, we conducted further investigation using $3 \mathrm{~mol} \%$ of catalyst to determine the reliability.

Since it is well recognized that ionic reactions are accelerated in an ionic liquid (IL) solvent system, we next tested the reaction in this type of system. Room temperature ionic liquids are a new class of solvents and have attracted growing interest recently because of their unique physical and chemical properties; they are non-volatile, non-flammable, have low toxicity and good solubility for many organic and inorganic materials. ${ }^{5}$ ) As expected, the reaction proceeded very smoothly in the ionic solvent system and the desired product $\mathbf{3 a}$ was obtained in excellent yield (Entries 7-13). It was found that we needed no tedious air bubbling treatment of the solvent when the reaction was carried out in an IL solvent; the reaction mixture was just stirred under open air atmospheric conditions, and $\mathbf{3 a}$ was obtained in excellent yield. As shown in Table 1, the results were signifi-

Table 1 Results of 1,4-addition reaction of ketoester $\mathbf{1 a}$ with vinyl ketone $\mathbf{2} \mathbf{a}^{\mathrm{a}}$.

\begin{tabular}{|c|c|c|c|c|c|c|c|}
\hline Entry & Catalyst & $\mathrm{mol} \%^{\mathrm{b}}$ & Conditions & Solvent & Time & $\begin{array}{l}\text { Yield } \\
\text { of } \mathbf{3} \mathbf{a}^{c}\end{array}$ & $\begin{array}{c}\text { Recovery } \\
\text { of } \mathbf{l a}^{\mathrm{c}}\end{array}$ \\
\hline 1 & $\mathrm{Fe}\left(\mathrm{ClO}_{4}\right)_{3} \cdot \mathrm{Al}_{2} \mathrm{O}_{3}$ & 3 & under argon & $\mathrm{CH}_{3} \mathrm{CN}$ & $24 \mathrm{~h}$ & $25 \%$ & $63 \%$ \\
\hline 2 & $\mathrm{Fe}\left(\mathrm{BF}_{4}\right)_{2} \cdot 6 \mathrm{H}_{2} \mathrm{O}$ & 3 & under argon & $\mathrm{CH}_{3} \mathrm{CN}$ & $6 \mathrm{~h}$ & $57 \%$ & $38 \%$ \\
\hline 3 & $\mathrm{Fe}\left(\mathrm{BF}_{4}\right)_{2} \cdot 6 \mathrm{H}_{2} \mathrm{O}$ & 3 & open air & $\mathrm{CH}_{3} \mathrm{CN}$ & $6 \mathrm{~h}$ & $73 \%$ & $10 \%$ \\
\hline 4 & $\mathrm{Fe}\left(\mathrm{BF}_{4}\right)_{2} \cdot 6 \mathrm{H}_{2} \mathrm{O}$ & 3 & + dry air ${ }^{d}$ & $\mathrm{CH}_{3} \mathrm{CN}$ & $3 \mathrm{~h}$ & $80 \%$ & $0 \%$ \\
\hline 5 & $\mathrm{Fe}\left(\mathrm{BF}_{4}\right)_{2} \cdot 6 \mathrm{H}_{2} \mathrm{O}$ & 1 & + dry $\operatorname{air}^{\mathrm{d}}$ & $\mathrm{CH}_{3} \mathrm{CN}$ & $5 \mathrm{~h}$ & $80 \%$ & $0 \%$ \\
\hline 6 & $\mathrm{Fe}\left(\mathrm{BF}_{4}\right)_{2} \cdot 6 \mathrm{H}_{2} \mathrm{O}$ & 0.1 & + dry air ${ }^{d}$ & $\mathrm{CH}_{3} \mathrm{CN}$ & $10 \mathrm{~h}$ & $67 \%$ & $19 \%$ \\
\hline 7 & $\mathrm{Fe}\left(\mathrm{BF}_{4}\right)_{2} \cdot 6 \mathrm{H}_{2} \mathrm{O}$ & 3 & open air & {$[\mathrm{bmim}]\left[\mathrm{BF}_{4}\right]$} & $2.5 \mathrm{~h}$ & $84 \%$ & $0 \%$ \\
\hline 8 & $\mathrm{Fe}\left(\mathrm{BF}_{4}\right)_{2} \cdot 6 \mathrm{H}_{2} \mathrm{O}$ & 3 & open air & {$[\mathrm{bmim}]\left[\mathrm{PF}_{6}\right]$} & $2.5 \mathrm{~h}$ & $84 \%$ & $2 \%$ \\
\hline 9 & $\mathrm{Fe}\left(\mathrm{BF}_{4}\right)_{2} \cdot 6 \mathrm{H}_{2} \mathrm{O}$ & 3 & open air & {$[\mathrm{bmim}]\left[\mathrm{NTf}_{2}\right]$} & $2 \mathrm{~h}$ & $95 \%$ & $0 \%$ \\
\hline 10 & $\mathrm{Fe}\left(\mathrm{BF}_{4}\right) 2 \cdot 6 \mathrm{H}_{2} \mathrm{O}$ & 3 & open air & {$[\mathrm{bdmim}]\left[\mathrm{PF}_{6}\right]$} & $2 \mathrm{~h}$ & $95 \%$ & $0 \%$ \\
\hline 11 & $\mathrm{Fe}\left(\mathrm{BF}_{4}\right)_{2} \cdot 6 \mathrm{H}_{2} \mathrm{O}$ & 3 & open air & [demema] $\left[\mathrm{BF}_{4}\right]$ & $2.5 \mathrm{~h}$ & $93 \%$ & $3 \%$ \\
\hline 12 & $\mathrm{Fe}\left(\mathrm{BF}_{4}\right)_{2} \cdot 6 \mathrm{H}_{2} \mathrm{O}$ & 3 & open air & {$\left[\right.$ demema][ $\left.\mathrm{NTf}_{2}\right]$} & $0.5 \mathrm{~h}$ & $93 \%$ & $4 \%$ \\
\hline 13 & $\mathrm{Fe}\left(\mathrm{BF}_{4}\right)_{2} \cdot 6 \mathrm{H}_{2} \mathrm{O}$ & 3 & open air & {$\left[\right.$ bdmaetm] $\left[\mathrm{NTf}_{2}\right]$} & $0.5 \mathrm{~h}$ & $84 \%$ & $3 \%$ \\
\hline 14 & $\mathrm{Fe}\left(\mathrm{BF}_{4}\right)_{2} \cdot 6 \mathrm{H}_{2} \mathrm{O}$ & 3 & + dry air $^{\mathrm{d}}+\mathrm{TEMPO}^{\mathrm{f}}$ & $\mathrm{CH}_{3} \mathrm{CN}$ & $6 \mathrm{~h}$ & $0 \%$ & $36 \%$ \\
\hline 15 & $\mathrm{Fe}\left(\mathrm{BF}_{4}\right)_{2} \cdot 6 \mathrm{H}_{2} \mathrm{O}$ & 3 & open air+TEMPO & {$[\mathrm{bmim}]\left[\mathrm{NTf}_{2}\right]$} & $16 \mathrm{~h}$ & $64 \%$ & $0 \%$ \\
\hline 16 & $\mathrm{Fe}\left(\mathrm{BF}_{4}\right)_{2} \cdot 6 \mathrm{H}_{2} \mathrm{O}$ & 3 & open air+TEMPO & {$[\mathrm{bmim}]\left[\mathrm{NTf}_{2}\right]$} & $24 \mathrm{~h}$ & $0 \%$ & $88 \%$ \\
\hline
\end{tabular}

${ }^{\mathrm{a}} 1.5$ eq. vs. substrate was used. ${ }^{\mathrm{b}} 3 \mathrm{~mol} \%$ vs. substrate. ${ }^{\mathrm{c} I s o l a t e d}$ yield. ${ }^{\mathrm{d}}$ Dry air $(5 \mathrm{ml} / \mathrm{mmol}$ of the substrate) was bubbled into the solvent prior to the reaction. ${ }^{\mathrm{e}} 1.0$ eq. vs. substrate. ${ }^{\mathrm{f}} 3 \mathrm{~mol} \%$ vs. substrate.

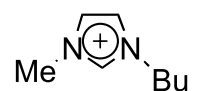

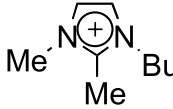

[bdmim]

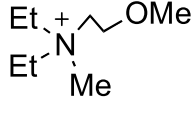

[demema]
$\mathrm{Me}_{2} \mathrm{~N}$

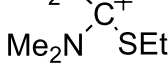

[bdmaetm] 
cantly dependent on the solvent system: [bmim][NTf $f_{2}$, $[$ bdmim $]\left[\mathrm{PF}_{6}\right]$, [demema $]\left[\mathrm{BF}_{4}\right],,^{11)}$ and [demema] $\left[\mathrm{NTf}_{2}\right]^{11}$ gave $3 \mathbf{a}$ in over $90 \%$ yield (Entries 12-15) and the highest yield was recorded for $[\mathrm{bmim}]\left[\mathrm{NTf}_{2}\right]$ or [bdmim] $\left[\left[\mathrm{PF}_{6}\right]\right.$ solvent (Entries 9 and 10). The most rapid reactions were accomplished for [demema] $\left[\mathrm{NTf}_{2}\right]$ or [bdmaetm] $\left[\mathrm{NTf}_{2}\right]^{12)}$ solvent system; 3a was obtained in $93 \%$ yield for $0.5 \mathrm{~h}$ of reaction in [demema][ $\left.\mathrm{NTf}_{2}\right]$ (Entry 12 ) and $84 \%$ for $\left[\right.$ bdmaetm] $\left[\mathrm{NTf}_{2}\right]^{12)}$ solvent system (Entry 13).

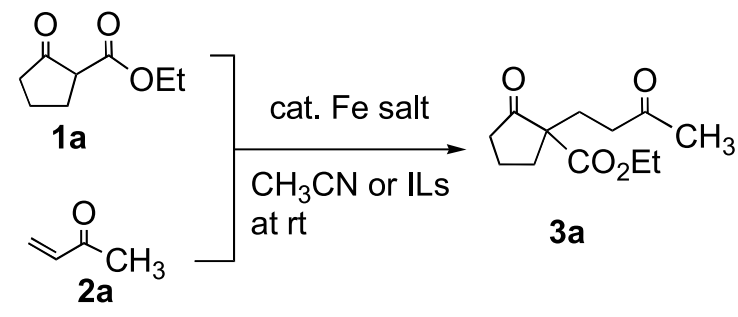

To gain the insight of the reaction mechanism of the present reaction, we tested the additive effect of 2,2,6,6tetramethyl-1-piperidinyloxy, free radical (TEMPO), since it was suspected that the reaction may proceed via a single electron oxidation pathway rather than a Lewis acid promoted reaction. ${ }^{13)}$ It is recognized that a radical reaction was inhibited by TEMPO due to trapping a radical intermediate. ${ }^{6)}$ The present reaction was supposed to be catalyzed by a trace amount of iron(III) cation. Hence we anticipated that the reaction might be inhibited by addition of TEMPO an equal amount of the catalyst. Interestingly, the inhibitory action of TEMPO was significantly depend on the reaction medium; as anticipated, the reaction was completely inhibited by TEMPO with an equal amount of the catalyst $(3 \mathrm{~mol} \%)$ in $\mathrm{CH}_{3} \mathrm{CN}$ (Entry 14), while it required 1.0 eq. of TEMPO to inhibit the reaction in the ionic liquid solvent (Entry 16). These results may suggest that catalytic mode of $\mathrm{Fe}\left(\mathrm{BF}_{4}\right)_{2}$ depend on the solvent system. Since TEMPO is reported to bind with the iron(III) cation and inactivate the catalytic property, ${ }^{6,7)}$ we attempted to isolate such a product, however, we isolated neither TEMPO-substrate complex nor TEMPO-Fe salt complex from the reaction mixture. ${ }^{14,15)}$

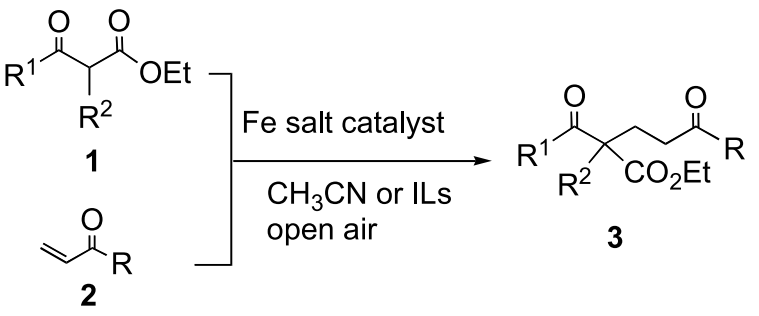

We next investigated the scope and limitation of the $\mathrm{Fe}\left(\mathrm{BF}_{4}\right)_{2} \cdot 6 \mathrm{H}_{2} \mathrm{O}$-catalyzed reaction (Eq. 2 and Table 2). Interestingly, $\mathrm{Fe}\left(\mathrm{ClO}_{4}\right)_{3} \cdot \mathrm{Al}_{2} \mathrm{O}_{3}$ did not work as catalyst when ethyl acetoacetate $\mathbf{l b}\left(\mathrm{R}^{1}=\mathrm{Me}, \mathrm{R}^{2}=\mathrm{H}\right)$ was subjected to the reaction (Entry 1); it was essential to use $\mathrm{Fe}\left(\mathrm{BF}_{4}\right)_{2}$ as catalyst for $\mathbf{l b}$ (Entry 2). Unfortunately, no reaction took place when diethyl malonate (1c) was used as the donor substrate (Entries 3 and 4). Since it is recognized that malonates do not form a chelate with iron(III) species, ${ }^{6}$ ) the 1,4 -addition reaction using ferric salt catalyst may be difficult. As mentioned before, the present reaction was inhibited by addition of TEMPO, therefore, it may involve a single electron pathway, however, we are now assuming that the present reaction may be explained by the ionic reaction mechanism; the ferric ion works very effectively as a Lewis acid catalyst, particularly in an ionic liquid solvent system.

We next demonstrated the recycled use of $\mathrm{Fe}\left(\mathrm{BF}_{4}\right)_{2}$. $6 \mathrm{H}_{2} \mathrm{O}$ catalyst in our reaction system (Table 3 ). To a mixture of $\mathbf{1 a}$ and $\mathbf{1 b}$ in $[\mathrm{bmim}]\left[\mathrm{NTf}_{2}\right]$ solvent was added 3 mol $\%$ of $\mathrm{Fe}\left(\mathrm{BF}_{4}\right)_{2} \cdot 6 \mathrm{H}_{2} \mathrm{O}$ under an air atmospheric condition and the mixture was stirred at $\mathrm{rt}$. The reaction course was monitored by TLC analysis at ten-minute intervals, and the reaction was quenched by addition of ether immediately after 1a had been consumed. Addition of ether to the reaction mixture formed the biphasic layer and the product $\mathbf{3 a}$ was isolated from the ether layer. The relative rate was calculated by the chemical yield of $\mathbf{3 a}$ in a certain reaction time (h). Since $\mathrm{Fe}\left(\mathrm{BF}_{4}\right)_{2}$ catalyst remained in the ionic liquid layer, it was possible to use the catalyst repeatedly. The product $\mathbf{3 a}$ was obtained in excellent yield in every run for ten consecutive times, while the reaction rate dropped with repetition of the reaction process. It was possible, however, to recover the reaction rate by adding the new catalyst as

Table 2 Results of 1,4-addition reaction of ketoesters $\mathbf{1}$ with vinyl ketones 2 .

\begin{tabular}{|c|c|c|c|c|c|c|c|}
\hline \multirow{2}{*}{ Entry } & Donor 1 & \multirow{2}{*}{$\begin{array}{c}\text { acceptor } 2^{\mathrm{a}} \\
\mathrm{R}\end{array}$} & \multirow{2}{*}{ Catalyst $^{\mathrm{b}}$} & \multirow{2}{*}{ Solvent } & \multirow{2}{*}{ Time } & \multirow{2}{*}{$\begin{array}{l}\text { Yield } \\
\text { of } \mathbf{3} \mathbf{a}^{\mathrm{c}}\end{array}$} & \multirow{2}{*}{$\begin{array}{c}\text { Recovery } \\
\text { of } \mathbf{1 a}^{\mathrm{c}}\end{array}$} \\
\hline & $\mathrm{R}^{1} \quad \mathrm{R}^{2}$ & & & & & & \\
\hline 1 & $\mathrm{CH}_{3} \quad \mathrm{H}$ & $\mathrm{CH}_{3}$ & $\mathrm{Fe}\left(\mathrm{ClO}_{4}\right)_{3} \cdot \mathrm{Al}_{2} \mathrm{O}_{3}$ & $\mathrm{CH}_{3} \mathrm{CN}^{\mathrm{d}}$ & $24 \mathrm{~h}$ & $0 \%$ & $83 \%$ \\
\hline 2 & $\mathrm{CH}_{3} \quad \mathrm{H}$ & $\mathrm{CH}_{3}$ & $\mathrm{Fe}\left(\mathrm{BF}_{4}\right)_{2} \cdot 6 \mathrm{H}_{2} \mathrm{O}$ & $\mathrm{CH}_{3} \mathrm{CN}^{\mathrm{d}}$ & $6 \mathrm{~h}$ & $53 \%$ & $11 \%$ \\
\hline 3 & EtO & $\mathrm{CH}_{3}$ & $\mathrm{Fe}\left(\mathrm{ClO}_{4}\right)_{3} \cdot \mathrm{Al}_{2} \mathrm{O}_{3}$ & $\mathrm{CH}_{3} \mathrm{CN}^{\mathrm{d}}$ & $24 \mathrm{~h}$ & $0 \%$ & $83 \%$ \\
\hline 4 & EtO $\mathrm{H}$ & $\mathrm{CH}_{3}$ & $\mathrm{Fe}\left(\mathrm{BF}_{4}\right)_{2} \cdot 6 \mathrm{H}_{2} \mathrm{O}$ & $\mathrm{CH}_{3} \mathrm{CN}^{\mathrm{d}}$ & $2.5 \mathrm{~h}$ & $0 \%$ & $63 \%$ \\
\hline 5 & $-\left(\mathrm{CH}_{2}\right)_{3^{-}}$ & $\mathrm{n}-\mathrm{C}_{5} \mathrm{H}_{11}$ & $\mathrm{Fe}\left(\mathrm{BF}_{4}\right)_{2} \cdot 6 \mathrm{H}_{2} \mathrm{O}$ & {$[\mathrm{bmim}]\left[\mathrm{NTf}_{2}\right]$} & $2 \mathrm{~h}$ & $86 \%$ & $12 \%$ \\
\hline 6 & $-\left(\mathrm{CH}_{2}\right)_{3^{-}}$ & $\mathrm{Ph}\left(\mathrm{CH}_{2}\right)_{2}$ & $\mathrm{Fe}\left(\mathrm{BF}_{4}\right)_{2} \cdot 6 \mathrm{H}_{2} \mathrm{O}$ & {$[\mathrm{bmim}]\left[\mathrm{NTf}_{2}\right]$} & $18 \mathrm{~h}$ & $76 \%$ & $4 \%$ \\
\hline 7 & $-\left(\mathrm{CH}_{2}\right)_{3-}$ & $\mathrm{Ph}$ & $\mathrm{Fe}\left(\mathrm{BF}_{4}\right)_{2} \cdot 6 \mathrm{H}_{2} \mathrm{O}$ & {$[\mathrm{bmim}]\left[\mathrm{NTf}_{2}\right]$} & $4 \mathrm{~h}$ & $45 \%$ & $25 \%$ \\
\hline 8 & $-\left(\mathrm{CH}_{2}\right)_{3^{-}}$ & OEt & $\mathrm{Fe}\left(\mathrm{BF}_{4}\right) 2 \cdot 6 \mathrm{H}_{2} \mathrm{O}$ & {$[\mathrm{bmim}]\left[\mathrm{NTf}_{2}\right]$} & $24 \mathrm{~h}$ & $0 \%$ & $77 \%$ \\
\hline
\end{tabular}

${ }^{a} 1.5$ eq. vs. substrate was used. ${ }^{b} 3 \mathrm{~mol} \%$ vs. Ketoester 1 . ' Isolated yield. d Dry air $(5 \mathrm{ml} / \mathrm{mmol}$ of the substrate) was bubbled into the solvent prior to the reaction. 
Table 3 Recyclable use of Fe-salt catalyst using IL solvent system.

\begin{tabular}{ccc}
\hline Run & ${\text { Yield of } 3 \mathbf{a}^{\mathrm{a}}}^{\mathrm{R}}$ & $\begin{array}{c}\text { Rate } \\
\left(\mathrm{mM} \mathrm{h}^{-1}\right)^{\mathrm{b}}\end{array}$ \\
\hline 1 & $92 \%$ & $2.0 \times 10^{3}$ \\
2 & $86 \%$ & $6.7 \times 10^{2}$ \\
3 & $91 \%$ & $5.0 \times 10^{2}$ \\
4 & $94 \%$ & $1.7 \times 10^{2}$ \\
5 & $91 \%$ & $5.6 \times 10^{1}$ \\
6 & $88 \%$ & $4.2 \times 10^{1}$ \\
7 & $91 \%$ & $2.8 \times 10^{1}$ \\
8 & $85 \%$ & $1.9 \times 10^{1}$ \\
9 & $88 \%$ & $1.7 \times 10^{1}$ \\
$10^{\mathrm{c}}$ & $79 \%$ & $1.0 \times 10^{3}$ \\
11 & $87 \%$ & $1.3 \times 10^{2}$ \\
$12^{\mathrm{d}}$ & $80 \%$ & $1.0 \times 10^{3}$ \\
13 & $80 \%$ & $8.0 \times 10^{1}$ \\
$14^{\mathrm{e}}$ & $81 \%$ & $1.5 \times 10^{3}$ \\
\hline
\end{tabular}

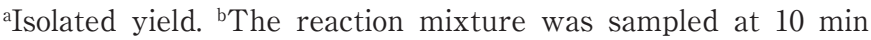
interval and monitored by TLC analysis. ${ }^{\mathrm{c}}$ Added $1.0 \mathrm{~mol} \%$ of catalyst. ${ }^{\mathrm{d}}$ Added $2.0 \mathrm{~mol} \%$ of catalyst. ${ }^{\mathrm{e}}$ Added $3 \mathrm{~mol} \%$ of catalyst.

shown in Table 3 (runs 10, 12, and 14). We thus succeeded in demonstrating the recyclable use of Fe-salt catalyst in our ionic liquid solvent system.

\section{Conclusion}

We discovered a novel $\mathrm{Fe}\left(\mathrm{BF}_{4}\right)_{2} \cdot 6 \mathrm{H}_{2} \mathrm{O}$ catalyst system for the 1,4-addition reaction of $\beta$-ketoesters with vinyl ketones. Although the reaction seems to be applicable only for limited substrates at present and the reaction mechanism is still unclear, it should be emphasized that the reaction is accomplished under absolutely neutral conditions. The reaction proceeds very smoothly at $\mathrm{rt}$ and requires no tedious argon atmospheric conditions. This is particularly important that the catalyst can be used repeatedly in the ionic liquid solvent system. Further investigation of the scope and limitations of this reaction will make it even more valuable.

\section{Acknowledgement}

This work is partly supported by Grant-in-Aid for Scientific Research from the Ministry of Education, Culture, Sports, Science, and Technology, Japan.

\section{References}

1) For recent reviews see: (a) C. Bolm, J. Legros, J. Le Paih, and L. Zani, L. Chem. Rev., 104, 6217 (2004), (b) A. Fürstner and R. Martin, Chem. Lett., 34, 624 (2005).

2) H. Ohara, K. Kudo, T. Itoh, M. Nakamura, and E. Nakamura, Heterocycles, 52, 505 (2000).

3) H. Ohara, T. Itoh, M. Nakamura, and E. Nakamura, Chem. Lett., 624 (2001).

4) (a) H. Ohara, H. Kiyokane, and T. Itoh, Tetrahedron. Lett., 43, 3041 (2002). (b) T. Itoh, K. Kawai, S. Hayase, and H. Ohara, Tetrahedron Lett., 44, 4081 (2003). (c) T.
Itoh, H. Uehara, K. Kawai, S. Hayase, H. Ohara, and M. Oyama, "Analytical Mechanistic and Synthetic Organic Electrochemistry- 6th International M. Baizer Award Symposium in Honor of Dennis H. Evans and Masao Tokuda", Eds. J. Lessard, P. Hapiot and I. Nishiguchi, The Electrochemical Society, Inc. USA p. 9 (2004).

5) For recent reviews of reactions in an ionic liquid solvent system see: (a) P. Wasserscheid and T. Welton (Eds), "Ionic Liquids in Synthesis", Wiley-VCH Verlag, (2003). (b) R. D. Rogers and K. R. Seddon (Eds), "Ionic Liquids as Green Solvents", ACS Symposium Series 856, American Chemical Society (2002). (c) N. Jain, A. Kumar, S. Chauhan, and S. M. S. Chauhan, Tetrahedron, 61, 1015 (2005).

6) For a recent review see: J. Christoffers, Eur. J. Org. Chem. 1259-1266 (1998).

7) J. Christoffers, J. Chem. Soc., Perkin Transactions 1: Organic and Bio-Organic Chemistry, 3141-3150 (1997): Chem. Commun. 1997, 943.

8) K. Shimizu, M. Miyagi, T. Kan-no, T. Kodama, and Y. Kitayama, Tetrahedron Lett., 44, 7421 (2003).

9) Recently extensive studies have been made on the 1,4addition reaction in an ionic liquid solvent system: (a) M. M. Dell'Anna, V. Gallo, P. Mastrorilli, C. F. Nobile, G. Romanazzi, and G. P. Suranna, Chem. Commun. 2002, 434. (b) R. C. Ranu, S. S. Dey, Tetrahedron, 60, 4183-4188 (2004). (c) X. Fan, X. Hu, X. Zhang, and J. Wang, Aust. J. Chem., 57, 1067 (2004). (d) J. S. Yadav, B. V. S. Reddy, G. Baishya, and A. V. Narsaiah, Chem. Lett., 34, 102 (2005). (e) B. C. Ranu and S. Banerjee, Org. Lett., 7, 3049 (2005). (f) Z. Wang, Q. Wang, Yu. Zhang, and W. Bao, Tetrahedron Lett., 46, 4657 (2005). (g) M. S. Rasalkar, M. K. Potdar, S. S. Mohile, and M. M. Salunkhe, J. Mol. Catalysis A: Chemical, 235, 267 (2005). (h) V. Gallo, D. Giardina-Papa, P. Mastrorilli, C. F. Nobile, G. P. Suranna, and Y. Wang, J. Organometallic Chem., 690, 3535 (2005).

10) T. Itoh, N. Ouchi, S. Hayase, and Y. Nishimura, Chem. Lett., 32, 654 (2003).

11) Diethyl(2-methoxyethyl)methylammonium bis(trifluoromethyl)sulfonylimide ([demema][ $\left.\mathrm{NTf}_{2}\right]$ ): for this ionic liquid, please contact with Dr. Gen Masuda of Nissinbo Co., Ltd. TEL: + 81-43-205-0795, FAX: + 81-43-205-0842.

12) Bisdimethylaminoethylthiometylium bis(trifluoromethyl)- sulfonyl-imide ([dmaetn][ $\left.\left.\mathrm{NTf}_{2}\right]\right)$ : for this unique novel ionic liquid, please contact with Dr. Yuan Gao or Ms. Kumiko Sueto of Kanto Denka Kogyo Co., Ltd. TEL: + 81-279-23-2712, FAX: + 81-279-25-1107.

13) We propose that our previously reported Fe salt-catalyzed reactions start from a single electron oxidation pathway. See references $2-4$.

14) Waymouth et al. recently reported that a radical coupling product with TEMPO was produced by the reaction of titanocene-TEMPO complex with epoxide. ${ }^{15)}$ So, we attempted to isolate TEMPO-adduct using 1.0 eq. of TEMPO, but only the Michel adduct 3a was detected by ${ }^{1} \mathrm{H}$ NMR. We are hoping that further investigation using Electron Paramagnetic Resonance (EPR) may provide more detailed information to elusidate the reaction mechanism of the present reaction. The study is now on the way of planning.

15) K-W. Huang, J. H. Han, A. P. Cole, C. B. Musgrave, and R. M. Waymouth, J. Am. Chem. Soc. 127, 3807 (2005). 